\title{
PRELIMINARY ADAPTATION INTO PORTUGUESE OF A STANDARDISED PICTURE SET FOR THE USE IN RESEARCH AND NEUROPSYCHOLOGICAL ASSESSMENT
}

SABINE POMPEIA*, ORLANDO F.A. BUENO*

\begin{abstract}
Pictorial stimuli and words have been widely used to evaluate mnemonic processes in clinical settings, neuropsychological investigations, as well as in studies on the mechanisms underlying the phenomena of memory. However, there seem to be few studies of standardisation of pictures for research in this field. The present paper aimed at adapting the use of a set of pictures standardised for English speaking subjects for Portuguese speakers. Name agreement of 150 pictures was assessed in 100 high-school students. Ninety pictures were found to present the same name for over 90 subjects. Results yield data that may help create more controlled tests for the study of memory for pictorial stimuli in Brazil.
\end{abstract}

KEY WORDS: explicit memory, implicit memory, repetition priming, pictures, neuropsychological tests.

\section{Adaptação preliminar para o português de conjunto de figuras padronizado para uso em pesquisa e avaliação psicológica}

RESUMO - Figuras e palavras há muito vêm sendo utilizadas para avaliar processos mnemônicos em investigações clínicas relacionadas a exames neuropsicológicos, bem como em estudos de mecanismos subjacentes ao fenômeno de memória. Existem, porém, poucos estudos de padronização de figuras para pesquisas nessas áreas. O presente estudo propõe uma adaptação preliminar para o português falado no Brasil de um conjunto de figuras padronizado para o idioma inglês. A consistência de nomeação de 150 figuras foi avaliada em 100 estudantes de segundograu. Noventa figuras apresentaram o mesmo nome por mais de 90 sujeitos. Resultados permitem auxiliar na criação de testes mais controlados de memória para desenhos de objetos comuns a serem utilizados no Brasil.

PALAVRAS-CHAVE: memória explícita, memória implícita, pré-ativação, figuras, testes neuropsicológicos.

It is now widely accepted that memory is comprised of a series of distinct phenomena and that it can be divided into subtypes which exhibit different characteristics. In 1985 Graf and Schacter proposed a systemic model of long-term memory which comprises an explicit, or "consciously" retrievable memory, and an implicit memory, retrievable without the aid of "conscious" strategies. Explicit memory can be considered to involve a so called semantic memory, responsible for factual, conceptual, impersonal knowledge, as well as an episodic memory which stores autobiographic information ${ }^{1}$. Implicit memory, on the other hand, includes learning which can be evaluated through performance such as skills, priming and classical conditioning ${ }^{2,3}$. Others ${ }^{4-6}$, however, suggest that the distinction between explicit and implicit memory does not reflect the existence of different memory systems but of distinct processing during acquisition and retrieval of information, which can be based on physical (perceptual) or conceptual characteristics. There are also authors who

*Departamento de Psicobiologia, Universidade Federal de São Paulo (UNIFESP), Brasil. Financial Support: AFIP, FAPESP, CNPq. Aceite: 30-abril-1998.

Dr. Orlando F.A. Bueno - Departamento de Psicobiologia - UNIFESP - Rua Botucatu 826, $1^{\circ}$ andar - 04023-062 São Paulo SP - Brasil - FAX: 011572 5092. E-mail: spompeia@psicobio.epm.br / ofabueno@psicobio.epm.br 
claim that the best approach is a mixed one, that considers both systemic and processing characteristics? ${ }^{7}$.

Whatever the criteria adopted for classifying memory, its subtypes are pragmatically distinguished by the tasks used to assess them ${ }^{8}$ which may include manipulation of both conceptual and perceptual features of words and pictures. However, the retrieval of words seems to involve different memory strategies from that of the latter stimuli, and yields lower memory performance ${ }^{9-11}$. One generally accepted explanation for this "picture superiority effect" is that pictures are represented in a rich sensory-perceptual code and have direct access to semantic processing, whereas words only initiate phonemic and orthographic processes and lexical access ${ }^{12}$. References on use of words to study memory are nevertheless much more widespread than for that of pictorial stimuli. One of the reasons for this difference may be that there are few studies of picture standardisation, which is more complex than for words mainly because of the fact that even the simplest objects can be represented in endless ways.

In order to enhance confidence of studies which investigate phenomena involved in the encoding of pictures, Snodgrass \& Vanderwart ${ }^{13}$ carried out a standardisation of 260 pictures of common objects drawn in black over a white background. These stimuli where selected according to variables considered important for memory processes and were drawn so as to obey pre-determined rules that permit evaluation of consistency between them (e.g. number of details, orientation, size of drawings). The set of pictures mentioned has been used extensively in clinical settings, neuropsychological evaluations, as well as to evaluate mechanisms underlying the phenomena of memory. Among its practical uses are studies on dissociation of explicit and implicit memory ${ }^{11,14}$, forgetting rates ${ }^{15}$, recognition ${ }^{10,12,16,17}$, hypermnesia ${ }^{18}$ and repetition priming ${ }^{11,19-23}$, which taken together show that specific features of pictures are important in different memory tasks. Name agreement, or the rate at which objects depicted in the drawings are referred to with the same word or name, is certainly among the most important characteristics ${ }^{13}$.

Considering the importance of studies on memory it is surprising that there are no studies of standardisation of pictorial stimuli in Brazil. The present paper proposes an adaptation of part of the set of pictures proposed by Snodgrass \& Vanderwart ${ }^{13}$ for use in the construction of tests to be applied in Portuguese speaking subjects in Brazil. Naming of 150 pictures from the original set was studied in 100 high-school students. These pictures were selected because they present low to moderate complexity and area which enables the creation of distinct fragmented images (in 8 levels) of the complete drawing ${ }^{19}$ (Fig 1) that can be used to study repetition priming. In this case, memory is indexed by ease of identification of pictures to which subjects were exposed to from fragments as compared to that of fragments of unseen drawings ${ }^{21,23}$.

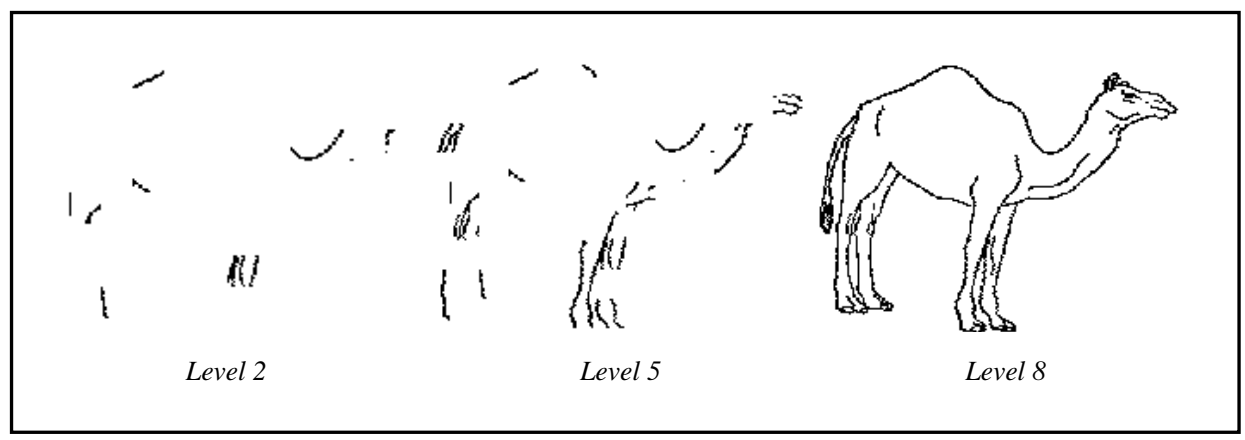

Fig 1: Example of a picture of the original set ${ }^{13}$ (picture no. 43-Camel) with levels 2, 5 and 8 of fragmentation ${ }^{19}$. (Printed by permission of Dr. J. G. Snodgrass). 


\section{METHODS}

\section{Subject}

One hundred high-school students from institutions around the city of São Paulo, Brazil, aged 20.0 \pm 5.3 years $($ mean $\pm \mathrm{SD})$ ranging from 15 to 39 years. All subjects were native Portuguese speakers.

\section{Stimuli}

One hundred and fifty pictures from Snodgrass \& Corwin's ${ }^{19}$ work were used (Pictures, digitized or as slides, are available from Life Science Associates, 1 Fenimore Rd., Bayport, NY 11705-2115, USA. e-mail: franksa@aol.com). These pictures are drawn in black over white background and present low to moderate complexity and sufficient area to enable the creation of distinctly different fragmented images.

\section{Procedure}

a. Naming: forms containing the 150 pictures printed on 6 sheets of paper were handed out to subjects during class and they received written instructions to write the name of each object bellow its representation. In case of problems in naming they should indicate if the picture was difficult to identify (di), difficult to name (dn), whether they did not know its name (kn) or did not identify the representation (ni). Order of pictures was varied in 3 different versions. Subjects were also instructed to complete 137 word stems so that tendency and rank completion could be established in order to create adequate word priming tests. These results will be published elsewhere (Pompéia \& Bueno, in preparation).

b. Consistency estimates: three criteria were used:

i. Simple name consistency: ascribed to pictures which received the same name by more than 90 subjects.

ii. Name consistency with specifications: ascribed to pictures named with simple name and name as a subclass of the most common name of the picture (i.e. polar bear for bear) resulting in more than 90 comparable names.

iii. Identification consistency: attributed to pictures which were named with common synonyms by more than 90 subjects (i.e. "TV“" "TV set" and "television").

Picture names are presented in Table 1 in alphabetical order according to the most frequent names assigned to them by subjects, frequency of most common name and other names. Pictures are also numbered according to Snodgrass \& Vanderwart ${ }^{13}$.

\section{RESULTS}

Following the criteria adopted in this paper, i.e., that agreement in naming or identifying should exceed 90 subjects for consistency to be present, simple name consistency was found for 90 pictures, name consistency with specifications for 5 and identification consistency for 6 drawings.

Problems in naming were seldom indicated. Nineteen subjects referred not knowing the name of picture 249 (wagon), 14 subjects of picture 207 (sled), 9 of picture 243 (trumpet), 7 of pictures 17 (barn) and 80 (drum), 5 of picture 95 (football), 4 of picture 190 (rolling pin) and 3 subjects of pictures 150 (mushroom), 31 (eagle), 80 (mitten) and 234 (toaster). Difficulty in naming was referred by 3 subjects in respect to picture 80 (drum) and 5 subjects to picture 248 (violin). Only 11 subjects referred picture 207 (sled) as difficult to identify.

\section{DISCUSSION}

Name and identification consistency were considered here as the main variables to be investigated for they probably reflect more accurately the differences between subjects of different native languages. However, other factors which are found to be important for picture memorisation and were also studied by Snodgrass \& Vanderwart ${ }^{13}$ such as familiarity with object, visual complexity, agreement between mental image and drawing were not studied in the present investigation. Although it is not possible to determine the similarity between such populations concerning these other factors without an effective study, it is probable that they are more closely related when name consistency and identification are equivalent. 
Pictures can be selected from Table 1 so as to fit the requirements of different research objectives such as constructing tests to investigate semantic and episodic memory, repetition priming effects, memorisation by populations with different characteristics, evaluation of amnestic effects of drugs, as well as memory impairment caused by amnestic disorders or damage to brain functioning.

Name agreement thus serves as an indication that drawings represent known objects which will be named consistently at recall and that are probably similar in terms of the variables considered important for memory processes determined for the picture set in English ${ }^{13}$. For an example of how to use the data described here, consider that different versions of a memory test for drawings has to be constructed to evaluate subjects in 4 sessions during a treatment programme. In this case, versions containing the same number of stimuli balanced according to name agreement should be used in order to establish comparability between them. In other words, if versions differ in terms of difficulty in naming it is possible that alterations in memory along the treatment may be distorted or masked. Also, in order to diminish effects of differences in difficulty of recalling pictures between versions it is necessary to balance the presentation between subjects and test groups. In terms of the method of applying the test, pictures from each set can be presented in various forms (e.g. cards, computer screen) for periods of time determined as adequate for the population under investigation and subjects may be asked to process them in different manner (e.g. perceptually, conceptually) or simply to try to remember them for a forthcoming memory test. Later they may be asked to, for instance: a) freely recall the drawings seen or recognise them among various figures which were not presented, in which case explicit memory would be evaluated; b) see fragments of the pictures presented previously (available in 8 levels; from Life Science Associates, see Methods) and determine at which level they are identified in comparison to drawings which were not shown, making it a repetition priming test.

If the work to be conducted aims at picture recognition and is not dependent on precise naming, for instance, stimuli with identification and name consistency with specifications can be used in addition to those with high name agreement. Nevertheless, it must be kept in mind that the criteria used in the present investigation was conservative. Differences between the naming of picture number 43 (Fig 1) in this study as camel or dromedary (dromedaries have only one hump while camels have 2), may be of no importance in the study to be conducted. Instead, the researcher may need to use such a picture in order to test categorisation of four footed animals, in which case the use of this particular picture is justifiable. Snodgrass \& Vanderwart ${ }^{13}$ also presented pictures organised into categories, information useful in studies of semantic memory. For another example of how to use results from the present study, one may evaluate memory for pictures which belong to different categories such as animals and tools taking care to select items from each category which have similar name agreements. In this case, the use of stimuli that belong to a standardised set in which categorisation was studied, even if in another language, is indispensable and has not been able to be carried out in Brazil until now due to lack of studies in this field. This is obviously valid as long as pictures are determined as being known and named in the idiom in which research is to be conducted.

It must be said, however, that regional, social, educational, age and possibly gender differences ${ }^{24}$ in naming may occur, so a pilot study to check similarity in naming between the population to be investigated and the one presented here is recommended.

Thus, result presented here should be used as a guide to the selection of pictorial stimuli to be used in the creation of test to assess any subtype of memory. The evaluation of the capacity to name and identify pictures from Snodgrass \& Corwin's ${ }^{19}$ work by a population of Brazilian high-school students may contribute to research in several fields, diminishing distortions resulting from noncontrolled features of pictorial stimuli used in tasks of memory evaluation.

Acknowledgments - We thank Ruth Ferreira dos Santos for help in collecting the data and Dr. J.G. Snodgrass for permission to publish drawings from the original pictures set. 
Table 1. Names and frequency (freq.) of use by 100 Portuguese speaking high-school students of 150 pictures numbered (no.) and named (concept) according to the original standardised set in English ${ }^{13}$. Consistency is indicated by: capital letters, simple name consistency (>90 subjects); *, pictures with name consistency with specifications; **, pictures with identification consistency.

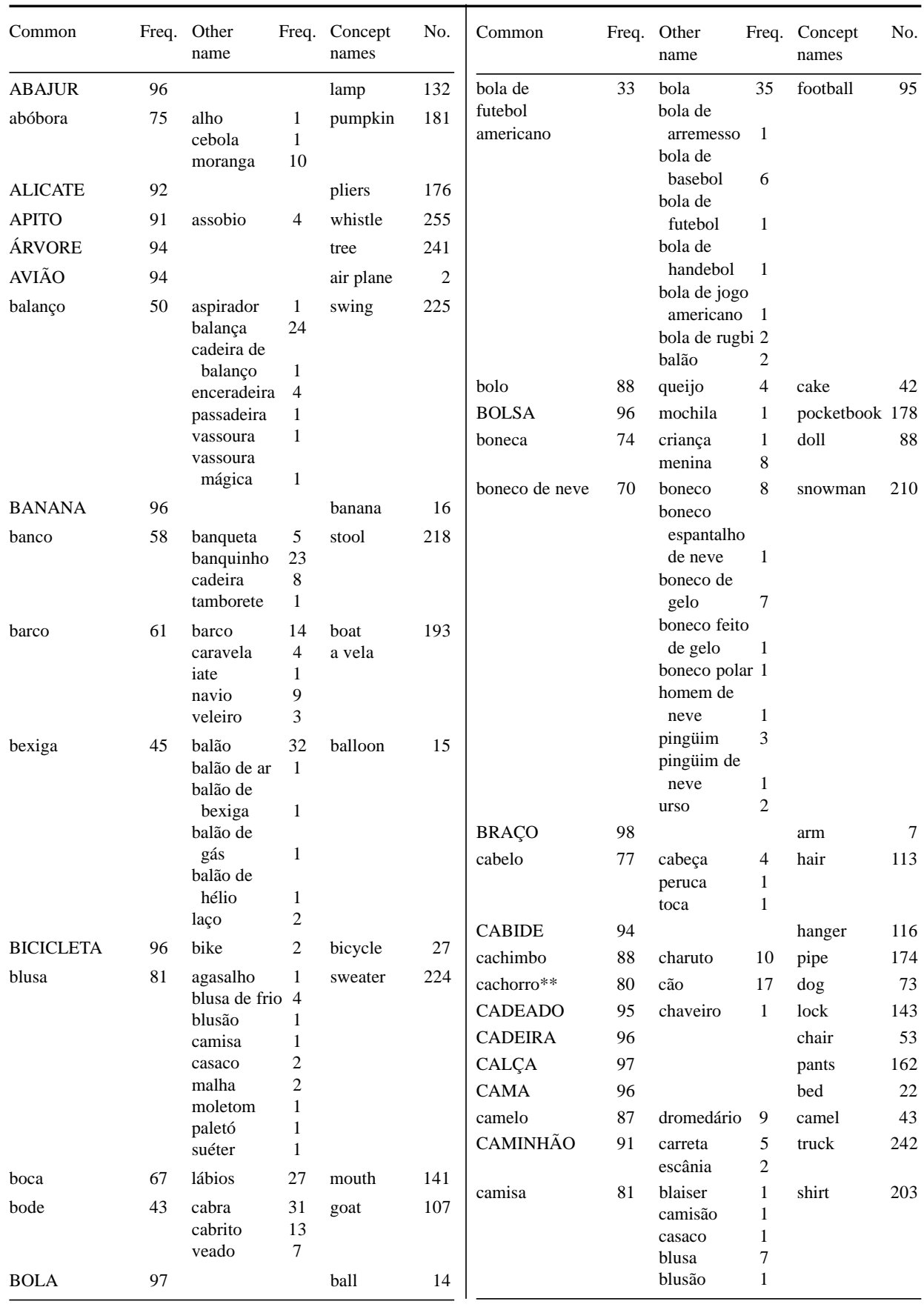


Table 1. (continued).

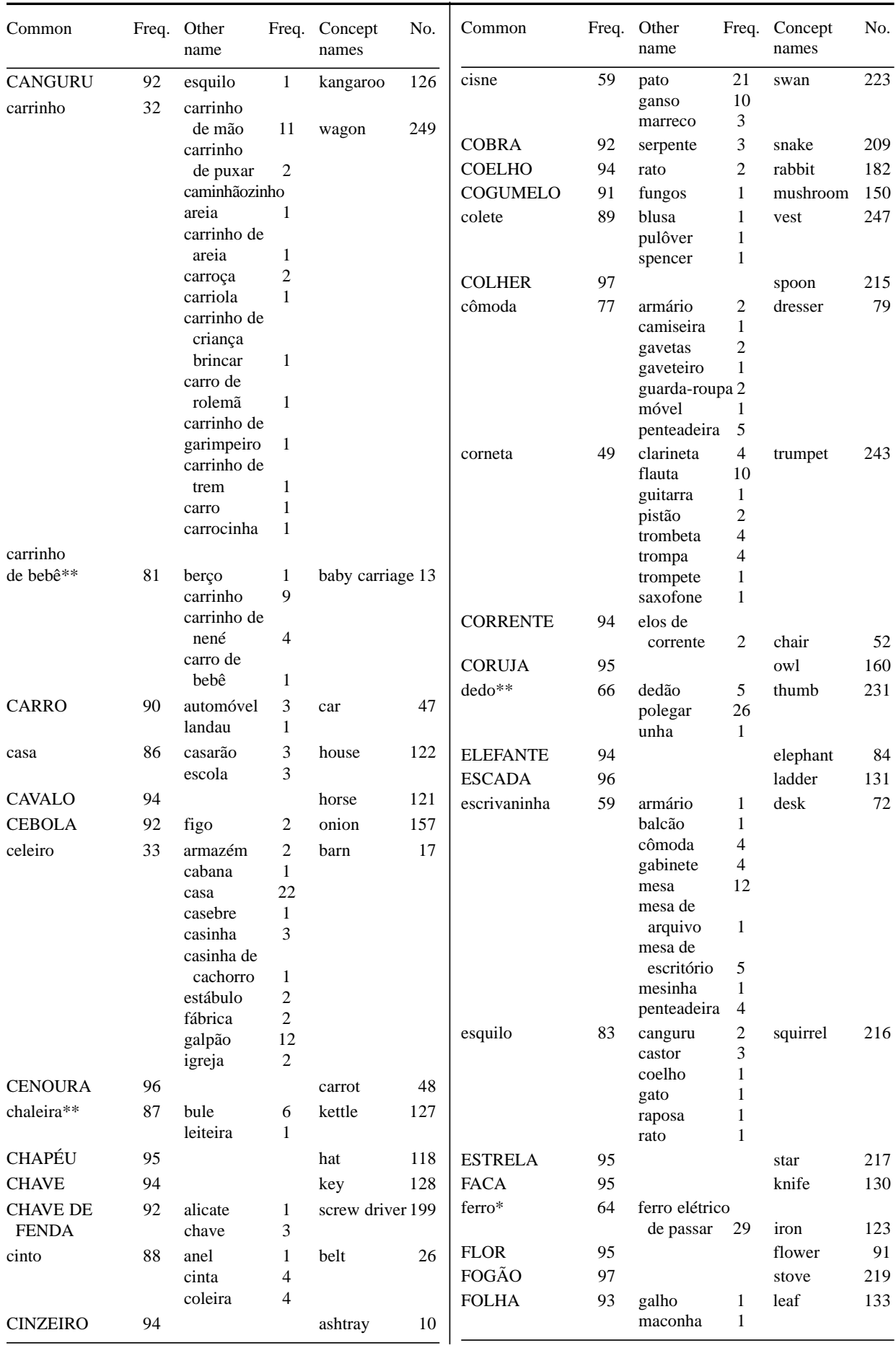


Table 1. (continued).

\begin{tabular}{|c|c|c|c|c|c|c|c|c|c|c|c|}
\hline Common & Freq. & $\begin{array}{l}\text { Other } \\
\text { name }\end{array}$ & Freq. & $\begin{array}{l}\text { Concept } \\
\text { names }\end{array}$ & No. & Common & Freq. & $\begin{array}{l}\text { Other } \\
\text { name }\end{array}$ & Freq. & $\begin{array}{l}\text { Concept } \\
\text { names }\end{array}$ & No. \\
\hline GARRAFA & 91 & litro & 3 & bottle & 32 & MORANGO & 93 & & & strawberry & 220 \\
\hline GATO & 96 & & & cat & 49 & мOTO & 91 & motocicleta & 4 & motorcycle & 147 \\
\hline \multirow[t]{9}{*}{ gavião } & \multirow[t]{9}{*}{31} & águia & 28 & \multirow[t]{9}{*}{ eagle } & \multirow[t]{9}{*}{82} & NARIZ & 94 & & & nose & 155 \\
\hline & & arara & 1 & & & ÓCULOS & 96 & & & glasses & 105 \\
\hline & & $\begin{array}{l}\text { ave } \\
\text { carcará }\end{array}$ & $\begin{array}{l}1 \\
1\end{array}$ & & & OLHO & 94 & & & eye & 86 \\
\hline & & $\begin{array}{l}\text { carcará } \\
\text { corvo }\end{array}$ & $\begin{array}{l}1 \\
1\end{array}$ & & & ÔNIBUS & 95 & & & bus & 39 \\
\hline & & falcão & 1 & & & orelha & 82 & ouvido & 13 & ear & 83 \\
\hline & & papagaio & 5 & & & paletó & 29 & avental & 2 & coat & 64 \\
\hline & & pomba & 2 & & & & & blaiser & 10 & & \\
\hline & & pássaro & 12 & & & & & blusão & 1 & & \\
\hline & & tucano & 1 & & & & & camiseta & 1 & & \\
\hline GELADEIRA & 95 & armário & 1 & refrigerator & 185 & & & capa & 1 & & \\
\hline \multirow[t]{3}{*}{ gorila } & \multirow[t]{3}{*}{67} & chimpanzé & 8 & \multirow[t]{3}{*}{ gorilla } & \multirow[t]{3}{*}{108} & & & capa de & & & \\
\hline & & macaco & 18 & & & & & chuva & 1 & & \\
\hline & & orangotango & o 2 & & & & & casaco & 33 & & \\
\hline GRAVATA & 94 & & & tie & 232 & & & roupa & 1 & & \\
\hline \multirow{3}{*}{$\begin{array}{l}\text { GUARDA- } \\
\text { CHUVA }\end{array}$} & \multirow[t]{3}{*}{90} & guarda-sol & 4 & \multirow{3}{*}{ umbrella } & \multirow{3}{*}{245} & & & sobretudo & 2 & & \\
\hline & & para-quedas & 1 & & & & & terno & 7 & & \\
\hline & & sombrinha & 3 & & & & & uniforme & 3 & & \\
\hline HELICÓPTERO & 91 & avião & 3 & helicopter & 120 & PANELA & 97 & & & pan & 179 \\
\hline JARRA & 95 & pote & 1 & pitcher & 175 & pão* & 87 & bolo & 1 & bread & 36 \\
\hline LÁPIS & 94 & & & pencil & 168 & & & bolo pulmann & nn 1 & & \\
\hline LEÃO & 94 & & & lion & 140 & & & pão de forma & $\begin{array}{l}1 \\
8\end{array}$ & & \\
\hline \multirow[t]{7}{*}{ limão } & \multirow[t]{7}{*}{68} & castanha & 1 & \multirow[t]{7}{*}{ lemon } & 135 & pássaro & 44 & canário & 2 & bird & 28 \\
\hline & & fruta & 1 & & & & & passarinho & 39 & & \\
\hline & & goiaba & 1 & & & & & pardal & 5 & & \\
\hline & & laranja & 1 & & & & & periquito & 1 & & \\
\hline & & noz & 1 & & & & & pintinho & $\begin{array}{l}1 \\
1\end{array}$ & & \\
\hline & & ovo & 1 & & & & & $\begin{array}{l}\text { pintinno } \\
\text { rouxinol }\end{array}$ & $\begin{array}{l}1 \\
1\end{array}$ & & \\
\hline & & pêssego & 8 & & & & & sabiá & 1 & & \\
\hline LIVRO & 96 & & & book & 30 & patins & 80 & carrinho & 1 & roller skate & 189 \\
\hline LUA & 96 & & & moon & 146 & patints & 80 & mobilete & 1 & & \\
\hline luva & 81 & mão & 16 & glove & 106 & & & motinho & 1 & & \\
\hline luva & 80 & luva de bebê & ê 2 & mitten & 144 & & & moto & 1 & & \\
\hline & & luva de boxe & 5 & & & & & motoca & 2 & & \\
\hline & & luva de & & & & & & motocicleta & 1 & & \\
\hline & & cozinheiro & 1 & & & & & triciclo & 1 & & \\
\hline & & luva térmica & a 1 & & & & & velocímetro & 1 & & \\
\hline MAÇA & 96 & fruta & 1 & apple & 6 & pato & 84 & ave & 1 & duck & 81 \\
\hline macaco & 88 & chimpanzé & 1 & monkey & 145 & & & galinha & 2 & & \\
\hline & & mico & 3 & & & & & ganso & 1 & & \\
\hline MACHADO & 92 & enxada & 1 & axe & 12 & & & marreco & 3 & & \\
\hline & & chave & 1 & & & & & patinho & 1 & & \\
\hline & & foice & 1 & & & & & pomba & 1 & & \\
\hline & & martelo & 1 & & & PÉ & 95 & & & foot & 92 \\
\hline MALA & 96 & maleta & 1 & suitcase & 221 & PEIXE & 93 & & & fish & 89 \\
\hline & & valise & 1 & & & PENTE & 95 & & & comb & 62 \\
\hline MÃO & 91 & dedos & 1 & hand & 115 & PERA & 96 & & & pear & 166 \\
\hline MARTELO & 94 & & & hammer & 114 & PIANO & 95 & & & piano & 171 \\
\hline MEIA & 98 & & & sock & 211 & PIÃO & 92 & & & top & 238 \\
\hline MESA & 95 & & & table & 226 & PINGÜIM & 95 & & & penguin & 169 \\
\hline montanha & 76 & monte & 2 & mountain & 148 & PIPA & 90 & papagaio & 3 & kite & 129 \\
\hline & & $\begin{array}{l}\text { morro } \\
\text { pico }\end{array}$ & $\begin{array}{l}2 \\
7\end{array}$ & & & PORCO & 94 & rinoceronte & 1 & rhinoceros & 172 \\
\hline & & serra & 1 & & & RATO & 92 & camundongo & 01 & mouse & 149 \\
\hline & & vulcão & 4 & & & RÉGUA & 94 & fita métrica & 1 & ruler & 192 \\
\hline
\end{tabular}


Table 1. (continued).

\begin{tabular}{|c|c|c|c|c|c|c|c|c|c|c|c|}
\hline Common & Freq. & $\begin{array}{l}\text { Other } \\
\text { name }\end{array}$ & Freq. & $\begin{array}{l}\text { Concept } \\
\text { names }\end{array}$ & No. & Common & Freq. & $\begin{array}{l}\text { Other } \\
\text { name }\end{array}$ & Freq. & $\begin{array}{l}\text { Concept } \\
\text { names }\end{array}$ & No. \\
\hline \multirow[t]{5}{*}{ relógio* } & \multirow[t]{5}{*}{70} & \multirow{5}{*}{$\begin{array}{l}\text { despertador } \\
\text { relógio } \\
\text { despertador } \\
\text { relógio de } \\
\text { parede }\end{array}$} & 3 & \multirow[t]{5}{*}{ clock } & \multirow[t]{5}{*}{60} & \multirow{8}{*}{$\begin{array}{l}\text { TESOURA } \\
\text { tigela }\end{array}$} & 96 & & & scissors & 197 \\
\hline & & & & & & & 66 & bacia & 9 & bowl & 34 \\
\hline & & & or 1 & & & & & cuba & 1 & & \\
\hline & & & & & & & & cuia & 3 & & \\
\hline & & & 20 & & & & & pires & 1 & & \\
\hline \multirow[t]{2}{*}{ relógio* } & \multirow[t]{2}{*}{84} & relógio de & & & & & & travessa & 3 & & \\
\hline & & pulso & 8 & watch & 250 & & & vasilha & 10 & & \\
\hline REVÓLVER & 92 & arma & 3 & gun & 112 & & & vasilhame & 1 & & \\
\hline \multirow[t]{9}{*}{ rolo macarrão } & \multirow[t]{9}{*}{24} & pau de & & \multirow{9}{*}{ rolling pin } & \multirow{9}{*}{190} & \multirow[t]{4}{*}{ tigre } & \multirow[t]{4}{*}{52} & gato & 2 & tiger & 233 \\
\hline & & macarrão & 9 & & & & & leopardo & 2 & & \\
\hline & & pau de massa & sa 4 & & & & & lobo & 1 & & \\
\hline & & & 28 & & & & & onça & 40 & & \\
\hline & & $\begin{array}{l}\text { rolo de } \\
\text { amassar }\end{array}$ & 2 & & & torradeira & 80 & assadeira & & & \\
\hline & & rolo de & & & & & & de pão & 1 & toaster & 234 \\
\hline & & massa & 18 & & & & & fogão & 1 & & \\
\hline & & rolo de & & & & & & forninho & 1 & & \\
\hline & & pastel & 2 & & & & & tanque & 1 & & \\
\hline \multirow{14}{*}{$\begin{array}{l}\text { SAIA } \\
\text { saleiro }\end{array}$} & 93 & saiote & 1 & skirt & 205 & & & tostadeira & 6 & & \\
\hline & 74 & colocador & & & & & & tostador & 1 & & \\
\hline & & $\begin{array}{l}\text { de sal } \\
\text { garrafa }\end{array}$ & 1 & barn & 94 & TREM & 90 & bonde & 1 & train & 240 \\
\hline & & de café & 1 & & & trenó & 16 & metro & 4 & & \\
\hline & & $\begin{array}{l}\text { garrafa } \\
\text { térmica }\end{array}$ & 1 & & & & & de praça & 1 & sled & 207 \\
\hline & & paliteiro & 1 & & & & & cadeira & & & \\
\hline & & pimenta & 1 & & & & & de praia & 1 & & \\
\hline & & pimenteiro & 1 & & & & & carrinho & & & \\
\hline & & porta sal & 2 & & & & & de esquiar & 1 & & \\
\hline & & pote de sal & 1 & & & & & esqueite & 1 & & \\
\hline & & salgueiro & 1 & & & & & esqui & 17 & & \\
\hline & & salino & 1 & & & & & lâmina & 2 & & \\
\hline & & tempero & 1 & & & & & maca & 2 & & \\
\hline & & vidro de sal & 1 & & & & & prancha & & & \\
\hline sanduíche & 83 & lanche & 8 & sandwich & 195 & & & de esquiar & 1 & & \\
\hline & & pizza & 1 & & & URSO & 93 & leão & 1 & bear & 21 \\
\hline & & sanduba & 1 & & & & & urso polar & 2 & & \\
\hline & & x-salada & 2 & & & uvas* & 82 & cacho & & & \\
\hline SAPATO & 95 & & & shoe & 204 & & & de uva & 14 & grapes & 109 \\
\hline SAPO & 93 & & & frog & 100 & vaca & 87 & boi & 8 & cow & 68 \\
\hline SERROTE & 96 & serra & 1 & saw & 196 & VASO & 92 & & & vase & 246 \\
\hline SOFÁ & 96 & & & sofa & 67 & VASSOURA & 95 & & & broom & 37 \\
\hline SOL & 93 & & & sun & 222 & VELA & 97 & & & candle & 44 \\
\hline tambor & 55 & bumbo & 8 & drum & 80 & VESTIDO & 91 & roupa & 6 & dress & 78 \\
\hline & & cuíca & 1 & & & & & conjunto & & & \\
\hline & & instrumento & 1 & & & & & feminino & 1 & & \\
\hline & & lata de lixo & 1 & & & violão & 89 & viola & 4 & guitar & 111 \\
\hline & & $\begin{array}{l}\text { l1Xo } \\
\text { pandeiro }\end{array}$ & 1 & & & violino & 72 & guitarra & 6 & violin & 248 \\
\hline & & tamborim & 7 & & & & & viola & 1 & & \\
\hline & & timba & 2 & & & & & violão & 5 & & \\
\hline & & zabumba & 2 & & & & & violoncelo & 1 & & \\
\hline TELEFONE & 91 & aparelho de & & & & vitrola & 76 & aparelho & & record- & \\
\hline & & telefone & 2 & telephone & 227 & & & de som & 1 & player & 184 \\
\hline televisão** & 86 & aparelho & & & & & & som & 1 & & \\
\hline & & de tv & 1 & television & 228 & & & radiola & 1 & & \\
\hline & & televisor & 2 & & & & & toca discos & 13 & & \\
\hline & & tv & 8 & & & XÍCARA & 94 & copo & 1 & cup & 70 \\
\hline
\end{tabular}




\section{REFERENCES}

1. Graf P, Schacter DL. Implicit and explicit memory for new associations in normal and amnesic subjects. J Exp Psychol Learn Mem Cogn 1985;11:501-518.

2. Squire LR. Mechanisms of memory. Science 1986;232:1612-1619.

3. Oliveira MGM, Bueno OFA. Neuropsicologia da memória. Psicologia USP 1993;4:117-138.

4. Blaxton TA. Investigating dissociations among memory measures: support for a transfer-appropriate processing framework. J Exp Psychol Learn Mem Cogn 1989;5:657-668.

5. Roediger HL. Implicit memory: retention without remembering. Am Psychol 1990;45:1043-1056.

6. Weldon MS. Mechanisms underlying priming on perceptual tests. J Exp Psychol Learn Mem Cogn 1991;17:526-541.

7. Tulving E, Schacter DC. Priming and human memory systems. Science 1990;247:301-306.

8. Richardson-Klavehn A, Bjork RA. Measures of memory. Ann Rev Psychol 1988;39:475-543.

9. Bajo, M-T. Semantic facilitation with pictures and words. J Exp Psychol Learn Mem Cogn 1988;14:579-589.

10. Dewhurst SA, Conway MA. Pictures, images, and recollective experience. J Exp Psychol Learn Mem Cogn 1994;20:1088-1098.

11. Weldon MS, Coyote KC. Failure to find the picture superiority effect in implicit conceptual memory tests. J Exp Psychol Learn Mem Cogn 1996;22:670-686.

12. Stenberg GS, Radeborg K, Hedman LR. The picture superiority effect in a cross-modality recognition task. Mem Cognit 1995;23:425-441

13. Snodgrass JG, Vanderwart M. A standardised set of 260 pictures: norms for name agreement, image agreement, familiarity, and visual complexity. J Exp Psychol Hum Learn Mem 1980;6:174-215.

14. Snodgrass JG, Hirshman E. Dissociations among implicit and explicit memory tasks: the role of stimuli similarity. J Exp Psychol Learn Mem Cogn 1994;20:150-160.

15. Hart RP, O'Shanick GJ. Forgetting rates for verbal, pictorial, and figural stimuli. J Clin Exp Neuropsychol 1993;15:245-265.

16. Friedman D. Cognitive event-related potential components during continuous recognition memory for pictures. Psychophysiology 1990;27:136-148.

17. Rajaram S. Perceptual effects on remembering: recollective processes in picture recognition memory J Exp Psychol Learn Mem Cogn 1996;22:365-377.

18. Payne DG, Anastasi JS, Blackwell JM, Wenger MJ. Selective disruption of hypermnesia for pictures and words. Mem Cognit 1994;22:542-551.

19. Snodgrass JG, Corwin J. Perceptual identification thresholds for 150 fragmented pictures from the Snodgrass and Vanderwart picture set. Percept Mot Skills 1988;67:3-36.

20. Snodgrass JG, Feenan K. Priming effects in picture fragment completion: support for the perceptual closure hypothesis. J Exp Psychol Gen 1990;119:276-296.

21. Sellal F, Danion J-M, Kauffmann-Muller F, et al. Differential effects of diazepam and lorazepam on repetition priming in healthy volunteers. Psychopharmacology (Berl) 1992;108:371-379.

22. Weldon MS, Jackson-Barret JL. Why do pictures produce priming on the word-fragment completion test? A study of encoding and retrieval factors. Mem Cognit 1993;21:519-528.

23. Vidailhet P, Danion J-M, Kauffmann-Muller F, et al. Lorazepam and diazepam effects on memory acquisition in priming tasks. Psychopharmacology (Berl) 1994;115:397-406.

24. Anooshian CJ, Seibert PS. Conscious and unconscious retrieval in picture recognition: a framework for exploring gender differences. J Pers Soc Psychol 1996;70:637-645. 